\title{
Water Loss by Evaporation from China's South-North Water Transfer \\ Project
}

Yu-Jun $\mathrm{Ma}^{12^{*}}$, Xiao-Yan $\mathrm{Li}^{1,2}$, Maxwell Wilson ${ }^{3}$, Xiu-Chen $\mathrm{Wu}^{1,2}$, Andrew Smith ${ }^{3}$, Jianguo $\mathrm{Wu}^{1,3}$

${ }^{1}$ State Key Laboratory of Earth Surface Processes and Resource Ecology, Beijing Normal University, Beijing 100875, China

${ }^{2}$ College of Resources Science and Technology, Beijing Normal University, Beijing 100875, China

${ }^{3}$ School of Life Sciences and School of Sustainability, Arizona State University, Tempe, AZ 85287, USA

Corresponding author: Yu-Jun Ma (Email: myj3648@ 163.com)

College of Resources Science and Technology

Beijing Normal University

No. 19, Xinjiekouwai Street, Haidian District

Beijing, 100875, China. 
Abstract: China's South-North Water Transfer Project (SNWTP) is the longest and largest water transfer project in world history. However, the evaporative loss from SNWTP is still unclear. Here we estimated the water loss by evaporation from the open canal and reservoir of the Middle Route of SNWTP (MR-SNWTP), based on field experiments and three mathematical models (Penman equation, Penman-Monteith equation, and Priestley-Taylor equation). Results showed that the Penman equation was the most reliable model, thus it was used to evaluate the evaporative loss from MR-SNWTP. Under the original planned scenario, average annual evaporative loss from the open canal and accompanying reservoir of MR-SNWTP would be approximately $9.00 \times 10^{8} \mathrm{~m}^{3}$, of which $35.28 \%$ results directly from the construction of MR-SNWTP (3.34\% of the planned total aqueduct diversion). However, during the first implement year of MR-SNWTP in 2015, the actual total water loss by evaporation was $6.43 \times 10^{8} \mathrm{~m}^{3}$, and the increased evaporative loss was $2.27 \times 10^{8} \mathrm{~m}^{3}$ due to the construction of MR-SNWTP, accounting for $8.57 \%$ of the actual total aqueduct diversion. This implies that the efficiency of MR-SNWTP from the perspective of water loss would be improved in the future with more water being transferred. Our results demonstrate that there is a general balance between water evaporation and vertical precipitation supplement of MR-SNWTP.

Keywords: China's South-North Water Transfer Project; evaporation; Penman equation; Penman-Monteith equation; Priestley-Taylor equation; water loss 


\section{Introduction}

Adequate access to water is essential for human well-being, socio-economic development, and healthy ecosystems. Though the total amount of water available will not diminish on a global scale due to hydrologic cycles, two-thirds of the world population could be under water stress by 2025 because of the uneven distribution of renewable freshwater resources in time and space (FAO 2014; Oki and Kanae 2006). The diversion of water from water-rich to water-poor areas has long been a tool to alleviate water stress in water-poor areas, such as the Central Arizona Project in United States (Guan et al. 2011), the Lesotho Highlands Water Project in Lesotho and South Africa (Matete and Hassan 2006), and the Tagus-Segura Transfer in Spain (Rey et al. 2016).

Water problems are particularly challenging in China, especially in the North China Plain (NCP), which is dominated by dry-land ecosystems and home to significant population, agriculture, and economic centers (Jeremy 2003). The annual water deficit in the NCP was 43 billion $\mathrm{m}^{3}$ in 2010, and may reach 48 billion $\mathrm{m}^{3}$ by 2050 (He et al. 2010). To alleviate the water resource shortage in the NCP, Chinese have developed significant water infrastructure, such as exploitation of more groundwater, desalination of saline waters, rainwater harvesting, wastewater recycling, and interbasin water transfers (Wei et al. 2007; Ma et al. 2008; Wang et al. 2009b). First conceived by Chairman Mao in the 1950s, the South-North Water Transfer Project (SNWTP) represents the grandest attempt to permanently solve the NCP's water woes. After a 
50-year feasibility study, the construction of SNWTP began in 2002, aiming to divert $4.5 \times 10^{10} \mathrm{~m}^{3} /$ year of water from the Yangtze basin to the NCP via three separate routes (CAB-SNWTP 2003). The Eastern Route (ER-SNWTP) moves water from the lower Yangtze River along a network of existing rivers, lakes, reservoirs, and canals. The Middle Route (MR-SNWTP) starts at Danjiangkou Reservoir on the Han River, the Yangtze's longest tributary, and begins to divert water through a new canal in December 2014. The Western Route plans to divert water from upper Yangtze River tributaries, but has not emerged from the planning phase because of complicated terrain and ecological concerns. Taken as a whole, SNWTP is the world's longest and largest water diversion project (Zhang et al. 2009), and will affect 13 provinces in north China (Fig. 1a), covering $3.57 \times 10^{6} \mathrm{~km}^{2}$ area (37.13\% of China's territory), and $5.81 \times 10^{8}$ people in 2014 (42.63\% of China's population) (NBSC 2015). Among the three routes, MR-SNWTP has attracted significant attention (Yan and Chen 2013; Li et al. 2015), because it is an absolutely newly-built water diversion project, and has evident economic, social and environmental impacts not only on the water-receiving areas (Jeremy 2003; Barnett et al. 2015), but also on the water-providing areas (Zhang et al. 2009; Gu 2012; Li 2013).

The construction of large water projects has always been an emotional and controversial issue (WCD 2000; Yevjevich 2001; Wu et al. 2003; Barnett et al. 2015). One important reason is water loss, which mainly includes evaporation, seepage, and bank storage. For example, in a similar water transfer project, the Central Arizona Project in United States, water loss accounted for $4 \%$ of the total aqueduct diversion in 
2012, and 85\% of this water loss was resulted from evaporation (CAP 2013). For MR-SNWTP, policy makers foresaw these potential losses and rejected the use of existing natural channels in favor of a new canal, which is covered with plastic and concrete in the bottom to limit seepage and bank storage. The vertical infiltration rate of these cover materials was less than $1.0 \times 10^{-11} \mathrm{~cm} / \mathrm{s}$ (Wang et al. 2009a), indicating that little water will loss by seepage and bank storage. However, mitigating evaporation, the only main potential water loss from MR-SNWTP, remains a challenge.

Evaporation is observably affected by multi-climatic conditions (Vörösmarty et al. 2000; Roderick and Farquhar 2002), and the spatiotemporal variations of pan evaporation in China, even in the same subzone, was significant (Zhang et al. 2015). MR-SNWTP crosses the humid and semi-humid region in China, with a length of 1420 km (Fig. 1b), but we have little information on the evaporative characteristics along the route as a whole. Until now, there has been no direct measurement of water evaporation inside the canal, and measured evaporation within the canal is now administratively difficult as the entire canal is surrounded by enclosures to limit accessibility. Therefore, we can't estimate is there any distinct difference of water evaporation inside the canal and at nearby weather stations, and evaluate the rationality of surrogating the former one by the later one.

According to the SNWTP administrative plan, after the construction of MR-SNWTP, the maximal impounded level of Danjiangkou Reservoir would increase from $157 \mathrm{~m}$ to $170 \mathrm{~m}$, expanding its maximal water surface area from $813 \mathrm{~km}^{2}$ to 1183 
$\mathrm{km}^{2}$. Though MR-SNWTP originally planned to transfer $9.5 \times 10^{9} \mathrm{~m}^{3}$ water annually from Danjiangkou Reservoir ("planned scenario"), it actually diverted approximately $2.65 \times 10^{9} \mathrm{~m}^{3}$ water from Danjiangkou Reservoir in 2015 (“2015 scenario”), after water transfer officially started on December 12, 2014. Because some supporting facilities in Henan Province and Hebei Province have not been completed, the actual aqueduct diversion under the 2015 scenario was evidently lower than called for in the planned scenario, and the planned total aqueduct diversion will be achieved gradually in the future (HD 2015). Due to the lower aqueduct diversion, the actual efficiency of MR-SNWTP was argued intensely (XN 2014). Water loss by evaporation can impact the efficiency of water transfer projects to a remarkable extent (CAP 2013), and knowledge gaps still exist on water loss from MR-SNWTP under different scenarios and its corresponding influence on the efficiency of MR-SNWTP.

The objective of this paper was to investigate the open water evaporative characteristic and water loss by evaporation from MR-SNWTP based on field measurements and mathematical models, and to discuss the efficiency of MR-SNWTP from the perspective of water loss. To our best knowledge, this study is the first to directly measure water evaporation inside the canal of MR-SNWTP, and the results of this work would fill a knowledge gap in our understanding of water loss from the world's largest water transfer project, and could be of critical importance for the sustainable management of MR-SNWTP. 


\section{Material and methods}

\subsection{Field experiments}

The entire canal of MR-SNWTP consists of $1191 \mathrm{~km}$ of open canal from Taocha (Fig. 1c) to the Beijuma River, $75 \mathrm{~km}$ of piping underground from Beijuma River to Tuancheng Lake in Beijing, and $154 \mathrm{~km}$ of branch line from Xihei Mountain to Outer Ring River in Tianjin (93 km aboveground and $61 \mathrm{~km}$ underground). Therefore, the evaporative length of the MR-SNWTP is approximately $1284 \mathrm{~km}$. There are 12 national weather stations with uniform spatial-distribution along the canal of MR-SNWTP, and the distances between the canal and nearby weather stations are all less than $30 \mathrm{~km}$ (Fig. 1b). Each of these national weather stations is equipped with an evaporation pan (E601B, Jiangsu Naiwch Corporation, China).

To assess the difference of evaporation between the canal and nearby weather stations, an identical E601B evaporation pan was installed within the canal near four weather stations, i.e. Shijiazhuang, Xinxiang, Nanyang, and Danjiangkou, respectively, and daily pan evaporation inside the canal was measured simultaneously with nearby weather stations from 13-29 July 2013. The installation of an E601B evaporation pan inside the canal was the same as that at nearby weather stations. First, a pit was dug and the evaporation barrel was put into the pit, keeping its upper brim aclinic and $30 \mathrm{~cm}$ above the land surface. Then, the surrounding accessorial ring was installed around the evaporation barrel, keeping its upper brim $7.5 \mathrm{~cm}$ lower than the upper brim of the evaporation barrel. Last, both the evaporation barrel and the accessorial ring were filled 
with water.
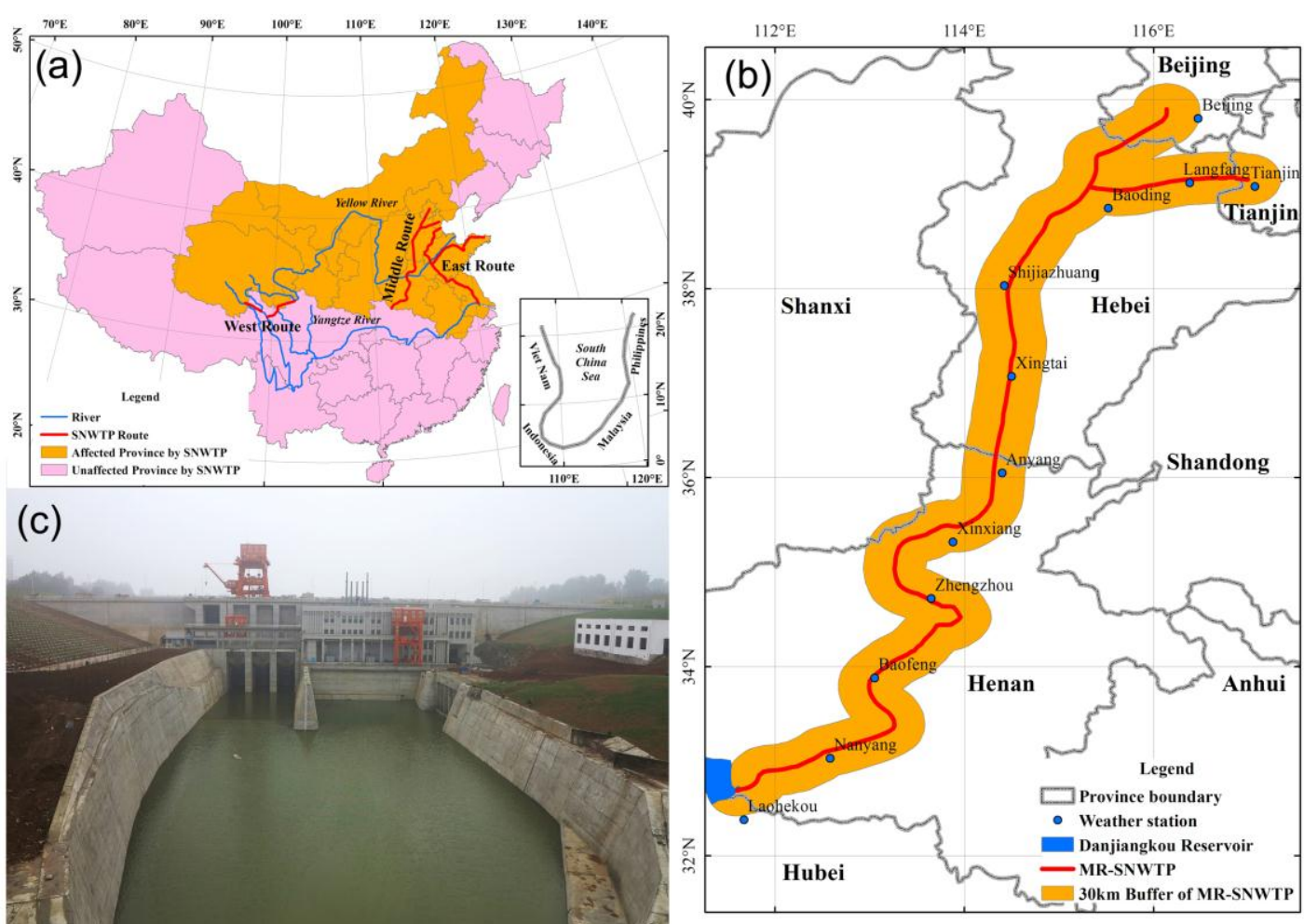

(c)

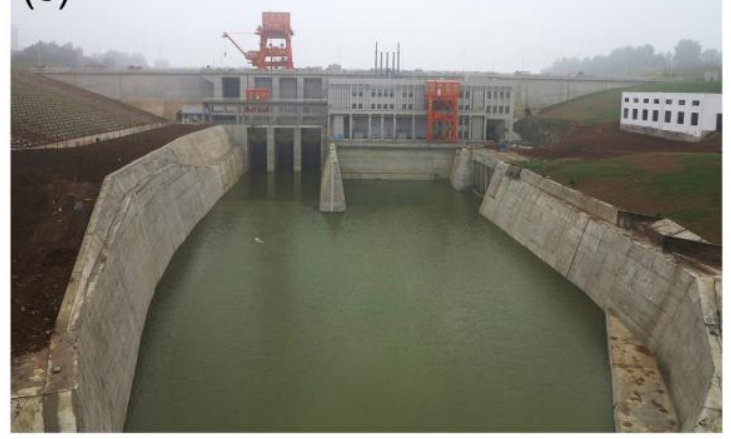

Fig. 1 Sketch map of China's South-North Water Transfer Project. (a) SNWTP will

affect 13 provinces in the North China Plain. (b) MR-SNWTP crosses Henan, Hebei, Beijing and Tianjin, with a length of $1420 \mathrm{~km}$ and 12 national weather stations near the canal. (c) The sluice at Taocha, head of MR-SNWTP. Both the bottom and the slope of the canal were covered by plastic film and concrete to reduce water seepage.

Based on the measured pan evaporation, the measured open water evaporation rate $\left(E_{m}, \mathrm{~mm} \mathrm{~d}^{-1}\right)$ inside the canal or at nearby weather stations was expressed by:

$$
E_{m}=E_{m, p a n} \times C
$$

where $E_{m, p a n}$ is the measured pan evaporation rate $\left(\mathrm{mm} \mathrm{d}^{-1}\right)$ inside the canal or at nearby weather stations; $C$ is the pan coefficient, a value that varies by month, with an 
annual mean value of 0.92 (Zhao, 2014).

In order to calculate water loss from MR-SNWTP, shape parameters of the canal, including the bottom elevation, slope angle, total slope length and bottom width near all 12 national weather stations, were measured directly by GPS locator, compass and measuring tape.

\subsection{Evaporation calculation}

Daily meteorological data (including maximum air temperature, minimum air temperature, atmospheric pressure, sunshine hours, relative humidity, wind speed, and measured pan evaporation) from 2000 to 2014 of all 12 nearby national weather stations were collected from China Meteorological Administration. Then, the open water evaporation rate was calculated by the Penman equation, Penman-Monteith equation, and Priestley-Taylor equation, respectively.

\subsubsection{Penman equation}

The classical form of Penman equation to estimate potential evaporation from open surface or a wet vegetated surface is (Penman 1948).

$$
E_{c, P}=\frac{\Delta}{\Delta+\gamma} \times \frac{R_{n}-G}{\lambda}+\frac{\gamma}{\Delta+\gamma} \times \frac{6.43 f_{(u)}\left(e_{s}-e_{a}\right)}{\lambda}
$$

where $E_{c, P}$ is open water evaporation rate calculated by Penman equation $\left(\mathrm{mm} \mathrm{d}^{-1}\right)$; $\Delta$ is slope of the saturation vapor pressure-temperature curve $\left(\mathrm{kPa}{ }^{\circ} \mathrm{C}^{-1}\right) ; \gamma$ is psychrometric constant $\left(\mathrm{kPa}{ }^{\circ} \mathrm{C}^{-1}\right) ; R_{n}$ is net radiation at the surface $\left(\mathrm{MJ} \mathrm{m}^{-2} \mathrm{~d}^{-1}\right) ; G$ is heat storage change in water $\left(\mathrm{MJ} \mathrm{m}^{-2} \mathrm{~d}^{-1}\right)$, and is not considered as it has been shown to be largely irrelevant for monthly or daily estimations in practical hydrological 
applications (Linacre 1993); $\lambda$ is latent heat of vaporization $\left(2.45 \mathrm{MJ} \mathrm{kg}^{-1}\right) ; f_{(u)}$ is wind function; $e_{s}$ is saturation vapor pressure $(\mathrm{kPa}) ; e_{a}$ is actual vapor pressure $(\mathrm{kPa})$. The calculation of above parameters is given in the Appendix.

\subsubsection{Penman-Monteith equation}

Penman-Monteith equation is an extension of Penman equation and can be applied to a range of surface vegetation (Monteith 1965).

$$
E_{c, P M}=\frac{\Delta\left(R_{n}-G\right)+\frac{\rho_{a} C_{p}\left(e_{s}-e_{a}\right)}{r_{a}} \times \frac{86400}{10^{6}}}{\lambda\left[\Delta+\gamma\left(1+\frac{r_{s}}{r_{a}}\right)\right]}
$$

where $E_{c, P M}$ is open water evaporation rate calculated by Penman-Monteith equation $\left(\mathrm{mm} \mathrm{d}^{-1}\right) ; \quad \rho_{a}$ is the air density $\left(\mathrm{kg} \mathrm{m}^{-3}\right) ; C_{p}$ is specific heat at constant pressure (1013 $\left.\mathrm{J} \mathrm{kg}^{-1}{ }^{\circ} \mathrm{C}^{-1}\right) ; \quad r_{a}$ is aerodynamic resistance $\left(\mathrm{m} \mathrm{s}^{-1}\right) ; r_{s}$ is bulk surface resistance $\left(\mathrm{m} \mathrm{s}^{-1}\right)$, equal to 0 for water body because the liquid particles are transferred freely into water vapor without passing through stem and xylem (Mohamed et al. 2012). Other variables are as defined in equation (2), and the calculation of $\rho_{a}$ and $r_{a}$ are given in the Appendix.

\subsubsection{Priestley-Taylor equation}

The Priestley-Taylor equation is based on the assumption that the effect of turbulence is small compared to the effect of radiation, and has been found to accurately estimate the evapotranspiration rates of large regions (Priestley and Taylor 1972; Tanny et al. 2008). 


$$
E_{c, P T}=\frac{D \Delta\left(R_{n}-G\right)}{\lambda(\Delta+\gamma)}
$$

where $E_{c, P T}$ is open water evaporation rate calculated by Priestley-Taylor equation $\left(\mathrm{mm} \mathrm{d}^{-1}\right) ; \quad D$ is a dimensionless parameter, equal to 1.26 over open water and saturated land (Priestley and Taylor 1972). Other variables are as defined in equation (2).

\subsection{Water loss calculation}

The evaporative width of the canal of MR-SNWTP was calculated using discharge data collected from the Construction and Administration Bureau of MR-SNWTP, and shape parameters of the canal measured as described above.

For an open canal and uniform flow, the hydraulic radius can be calculated by Manning formula (Manning 1891):

$$
R=V^{3 / 2} M^{3 / 2} K^{(-3 / 4)}
$$

where $R$ is hydraulic radius $(\mathrm{m}) ; V$ is flow velocity $\left(\mathrm{m} \mathrm{s}^{-1}\right) ; M$ is canal roughness, 0.015 for concrete surface according to the plan of MR-SNWTP; $K$ is hydraulic gradient, approximately equal to the surface slope, and could be determined on the basis of the surface topography (Quinn et al. 1991).

According to its definition, the hydraulic radius for a trapeziform canal can also be calculated as (Mayhew, 2015):

$$
R=\frac{\left(W_{b}+W_{b}+2 L \cos \beta\right) L \sin \beta}{2(W+2 L)}
$$

where $W_{b}$ is bottom width measured directly by measuring tape $(\mathrm{m}) ; L$ is wetted slope length $(\mathrm{m}) ; \quad \beta$ is slope angle measured directly by compass $\left(^{\circ}\right)$.

For a trapeziform canal and uniform flow, the average flow velocity can be 
calculated as follows.

$$
V=\frac{Q}{\frac{\left(W_{b}+W_{b}+2 L \cos \beta\right) L \sin \beta}{2}}
$$

where $Q$ is flow rate $\left(\mathrm{m}^{3} \mathrm{~s}^{-1}\right)$.

Based on equations (5), (6) and (7), $R, V$ and $L$ can be calculated. Then evaporative width $\left(W_{e}, \mathrm{~m}\right)$ inside the canal can be calculated as:

$$
W_{e}=W_{b}+2 L \cos \beta
$$

With this evaporative width, water loss from the whole open canal is calculated by:

$$
W L C=\sum_{i=1}^{12} E_{c, i} W_{e, i} l_{i}
$$

where $W L C$ is water loss by evaporation from the whole canal $\left(\mathrm{m}^{3} \mathrm{month}^{-1}\right) ; E_{c, i}$ is calculated monthly open water evaporation rate inside the canal near weather station $i$ $\left(\mathrm{mm}\right.$ month $\left.^{-1}\right)$ by the most reliable mathematical model (see 3.1$) ; W_{e, i}$ is the average evaporative width of the open canal controlled by weather station $i(\mathrm{~m}) ; l_{i}$ is the evaporative length of the open canal controlled by weather station $i(\mathrm{~km})$, and was determined by the location of weather stations and the bisector method, i.e. the meandering length of the open canal between two weather stations was divided equally into two half lengths, and the first half meandering length of the open canal was assumed to be controlled by one weather station while the second half meandering length was assumed to be controlled by the other weather station.

Water loss from the open reservoir was calculated as:

$$
W L R_{p}=1000 \times E_{c, 1} \times A_{p}
$$




$$
W L R_{e}=1000 \times E_{c, 1} \times A_{e}
$$

where $E_{c, 1}$ is calculated monthly open water evaporation rate inside the canal near Laohekou weather station $\left(\mathrm{mm}\right.$ month $^{-1}$ ), which is the nearest to Danjiangkou reservoir; $W L R_{p}$ is the water loss by evaporation from previous area of Danjiangkou reservoir before the construction of MR-SNWTP $\left(\mathrm{m}^{3} \mathrm{month}^{-1}\right) ; A_{p}$ is the previous area of Danjiangkou reservoir $\left(\mathrm{km}^{2}\right) ; W L R_{e}$ is the water loss by evaporation from expanded area of Danjiangkou reservoir because of the construction of MR-SNWTP $\left(\mathrm{m}^{3} \mathrm{month}^{-1}\right)$; $A_{e}$ is the expanded area of Danjiangkou reservoir $\left(\mathrm{km}^{2}\right)$. The sum of $A_{p}$ and $A_{e}$ is the actual total area of the Danjiangkou reservoir after the construction of MR-SNWTP.

Then, the total water loss by evaporation from MR-SNWTP can be calculated as follows.

$$
W L=W L C+W L R_{p}+W L R_{e}
$$

where $W L$ is the total water loss by evaporation from MR-SNWTP $\left(\mathrm{m}^{3} \mathrm{month}^{-1}\right)$, and the sum of $W L C$ and $W L R_{e}$ is the increased water loss because of the construction of MR-SNWTP.

The vertical water input by precipitation to MR-SNWTP was evaluated by the same method as the calculation of total water loss by evaporation, simply replacing open water evaporation rate $\left(E_{c, i}\right)$ and evaporative width $\left(W_{e, i}\right)$ in equation (9), (10) and (11) by precipitation $\left(P_{r, i}\right)$ and top width of the canal controlled by weather station $i$ $\left(W_{t, i}, \mathrm{~m}\right)$, respectively. The top width of the canal $\left(W_{t}, \mathrm{~m}\right)$ can be calculated as:

$$
W_{t}=W_{b}+2 L_{t} \cos \beta
$$


where $L_{t}$ is the total slope length measured directly by measuring tape (m), and other variables are as defined in equation (8).

\subsection{Statistical analysis}

Comparison between the measured and calculated monthly open water evaporation rates was carried out using simple linear regression $\left(E_{c, i}=\mu_{i} \times E_{m, i}\right)$, where $E_{c, i}$ is calculated open water evaporation at weather station $i\left(\mathrm{~mm} \mathrm{month}^{-1}\right), E_{m, i}$ is measured open water evaporation by E601B evaporation pan at weather station $i$ (mm month $^{-1}$ ), and $\mu_{i}$ is the regression coefficient at weather station $i$. Besides the determination coefficient of this linear regression $\left(R_{i}^{2}\right)$, root mean square error $\left(R M S E_{i}\right)$ and the Nash-Sutcliffe efficiency coefficient $\left(C_{i}\right)$ at weather station $i$ were also calculated to assess the performance of each model (Nash and Sutcliffe 1970).

$$
\begin{gathered}
R M S E_{i}=\sqrt{\frac{1}{m} \sum_{j=1}^{180}\left(E_{m, i, j}-E_{c, i, j}\right)^{2}} \\
C_{i}=1-\frac{\sum_{j=1}^{180}\left(E_{m, i, j}-E_{c, i, j}\right)^{2}}{\sum_{j=1}^{180}\left(E_{m, i, j}-\overline{E_{m, i, j}}\right)^{2}}
\end{gathered}
$$

where $E_{m, i}$ and $E_{c, i}$ are as previously defined; subscript $j$ indicates different monthly values and over bar indicates an average over the measurement period; 180 is the total number of months from 2000 to 2014.

\section{Results}

\subsection{Model performance}

There are two steps for the calculation of open water evaporation inside the canal. The first step is to choose a reliable mathematical model to calculate open water 
evaporation at nearby weather stations of MR-SNWTP, and the second step is to transfer open water evaporation at nearby weather stations to open water evaporation inside the canal. For the first step, monthly evaporation data from 2000 to 2014 were used to assess the performance of the Penman equation, Penman-Monteith equation, and Priestley-Taylor equation. Simple linear regression suggests that there was a good agreement between open water evaporation calculated by Penman equation and the measured value (Table 1). For the 12 national weather stations, root mean square error $(R M S E)$ values for the Penman equation were all less than $15 \mathrm{~mm} \mathrm{month}{ }^{-1}$, and the relative errors of the calculated monthly open water evaporation rate using the Penman equation were all lower than $10 \%$, with an average value of $1.1 \%$, indicating a near perfect approximation. Both the Penman-Monteith equation and the Priestley-Taylor equation underestimated the open water evaporation, with an average $R M S E$ of 13.72 $\mathrm{mm}$ month $^{-1}$ and $16.27 \mathrm{~mm}$ month $^{-1}$, respectively. Average Nash-Sutcliffee values of the Penman equation, Penman-Monteith equation, and Priestley-Taylor equation for all 12 weather stations are $0.87,0.86$ and 0.81 , respectively, indicating that the Penman equation better modeled actual open water evaporation than the Penman-Monteith or Priestley-Taylor methods. In general, the Penman equation was the most reliable model and was used to calculate open water evaporation at nearby weather stations of MR-SNWTP.

Table 1 Comparison of monthly calculated open water evaporation $\left(E_{c}\right)$ and measured open water evaporation $\left(E_{m}\right)$ by E601B evaporation pan at different 


\section{weather stations along MR-SNWTP from 2000 to 2014}

\begin{tabular}{|c|c|c|c|c|c|c|c|c|c|c|c|c|}
\hline \multirow{2}{*}{$\begin{array}{l}\text { Weather } \\
\text { Station }\end{array}$} & \multicolumn{4}{|c|}{ Penman equation } & \multicolumn{4}{|c|}{ Penman-Monteith equation } & \multicolumn{4}{|c|}{ Priestley-Taylor equation } \\
\hline & $\begin{array}{l}\text { Regression } \\
\text { Equation }\end{array}$ & $R^{2}$ & $\begin{array}{l}\text { RMSE } \\
\text { (mm/month) }\end{array}$ & $C$ & $\begin{array}{l}\text { Regression } \\
\text { equation }\end{array}$ & $R^{2}$ & $\begin{array}{l}\text { RMSE } \\
\text { (mm/month) }\end{array}$ & $C$ & $\begin{array}{l}\text { Regression } \\
\text { equation }\end{array}$ & $R^{2}$ & $\begin{array}{l}\text { RMSE } \\
\text { (mm/month) }\end{array}$ & $C$ \\
\hline Beijing & $E_{c, P}=0.951 E_{m}$ & 0.83 & 13.55 & 0.90 & $E_{c, P M}=0.859 E_{m}$ & 0.82 & 17.93 & 0.82 & $E_{c, P T}=0.779 E_{m}$ & 0.80 & 24.76 & 0.67 \\
\hline Tianjin & $E_{c, P}=1.095 E_{m}$ & 0.86 & 14.56 & 0.85 & $E_{c, P M}=0.987 E_{m}$ & 0.85 & 11.29 & 0.91 & $E_{c, P T}=0.886 E_{m}$ & 0.76 & 16.41 & 0.80 \\
\hline Langfang & $E_{c, P}=0.981 E_{m}$ & 0.85 & 12.78 & 0.91 & $E_{c, P M}=0.899 E_{m}$ & 0.83 & 14.67 & 0.88 & $E_{c, P T}=0.866 E_{m}$ & 0.80 & 17.36 & 0.83 \\
\hline Baoding & $E_{c, P}=1.022 E_{m}$ & 0.80 & 13.79 & 0.88 & $E_{c, P M}=0.939 E_{m}$ & 0.79 & 13.70 & 0.88 & $E_{c, P T}=0.914 E_{m}$ & 0.75 & 15.66 & 0.84 \\
\hline Shijiazhuang & $E_{c, P}=0.978 E_{m}$ & 0.73 & 14.82 & 0.85 & $E_{c, P M}=0.905 E_{m}$ & 0.71 & 15.89 & 0.83 & $E_{c, P T}=0.907 E_{m}$ & 0.68 & 17.12 & 0.80 \\
\hline Xingtai & $E_{c, P}=1.021 E_{m}$ & 0.83 & 12.93 & 0.89 & $E_{c, P M}=0.945 E_{m}$ & 0.82 & 12.92 & 0.89 & $E_{c, P T}=0.947 E_{m}$ & 0.80 & 13.86 & 0.87 \\
\hline Anyang & $E_{c, P}=1.018 E_{m}$ & 0.83 & 13.02 & 0.89 & $E_{c, P M}=0.934 E_{m}$ & 0.81 & 13.32 & 0.88 & $E_{c, P T}=0.907 E_{m}$ & 0.75 & 16.08 & 0.83 \\
\hline Xinxiang & $E_{c, P}=1.062 E_{m}$ & 0.85 & 12.47 & 0.87 & $E_{c, P M}=0.980 E_{m}$ & 0.85 & 10.69 & 0.91 & $E_{c, P T}=0.969 E_{m}$ & 0.84 & 11.82 & 0.89 \\
\hline Zhengzhou & $E_{c, P}=0.997 E_{m}$ & 0.86 & 10.76 & 0.91 & $E_{c, P M}=0.909 E_{m}$ & 0.85 & 12.84 & 0.88 & $E_{c, P T}=0.862 E_{m}$ & 0.81 & 16.65 & 0.79 \\
\hline Baofeng & $E_{c, P}=0.981 E_{m}$ & 0.75 & 13.68 & 0.86 & $E_{c, P M}=0.899 E_{m}$ & 0.72 & 15.42 & 0.82 & $E_{c, P T}=0.869 E_{m}$ & 0.65 & 18.64 & 0.74 \\
\hline Nanyang & $E_{c, P}=1.009 E_{m}$ & 0.79 & 11.60 & 0.87 & $E_{c, P M}=0.941 E_{m}$ & 0.78 & 11.95 & 0.87 & $E_{c, P T}=0.971 E_{m}$ & 0.75 & 12.82 & 0.85 \\
\hline Laohekou & $E_{c, P}=1.024 E_{m}$ & 0.44 & 14.83 & 0.73 & $E_{c, P M}=0.958 E$ & 0.43 & 14.03 & 0.76 & $E_{c, P T}=0.998 E_{m}$ & 0.49 & 14.04 & 0.76 \\
\hline
\end{tabular}

For the second step, the average measured daily open water evaporation rate inside the canal and at nearby weather stations were 2.02 and $1.93 \mathrm{~mm} \mathrm{~d}^{-1}$ respectively, during the field experiment periods. Regression analysis revealed a good agreement in measured daily open water evaporation rate between the canal $\left(E_{m, c a}\right)$ and nearby weather stations $\left(E_{m, w s}\right)$ (Fig. 2). A paired-samples T test also showed no evident difference in daily open water evaporation measured simultaneously inside the canal and at nearby weather stations. Thus, the open water evaporation at nearby weather stations provided adequate surrogates for that inside the canal, and the formula $E_{m, c a}=1.0372 E_{m, w s}$ was used to calculate open water evaporation inside the canal when open water evaporation at nearby weather stations was known. 


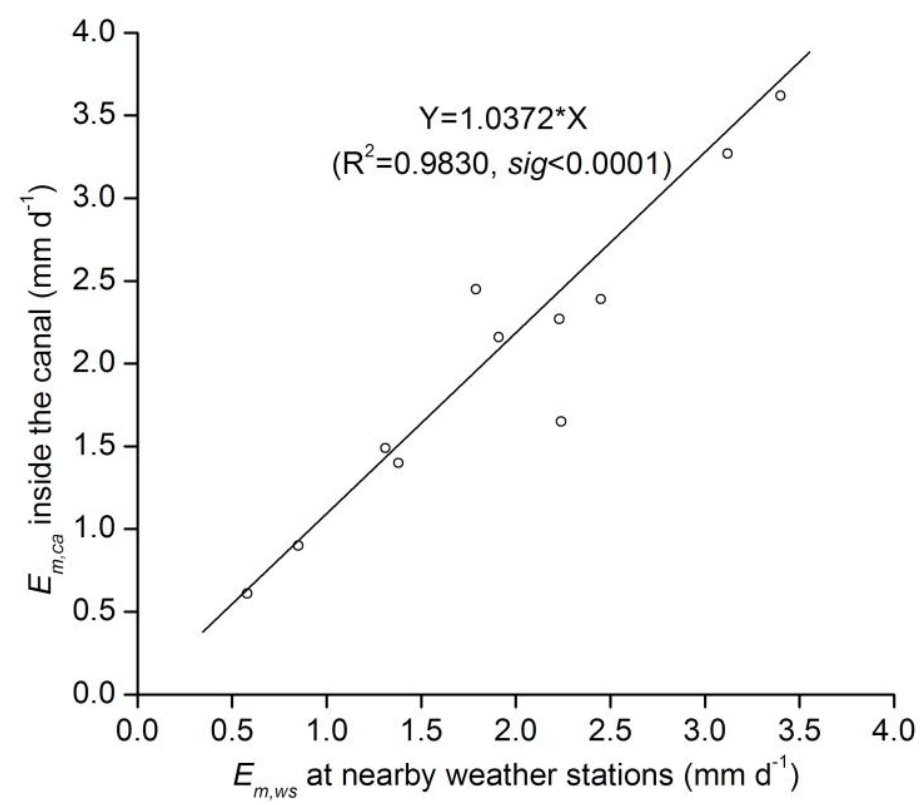

Fig. 2 Comparison of daily measured open water evaporation by E601B evaporation pan inside the canal and at nearby weather stations of MR-SNWTP from 13-29 July 2013

\subsection{Open water evaporation rate}

From 2000 to 2014, annual mean open water evaporation calculated by Penman equation varied significantly along MR-SNWTP (Fig. 3), mainly because of spatial gradients in climatic conditions. Open water evaporation of the five northern weather stations (Beijing, Tianjin, Langfang, Baoding, and Shijiazhuang) decreased from north to south. Though the air temperature increased gradually from Beijing (annual mean value $13.5{ }^{\circ} \mathrm{C}$ from 2000 to 2014 , similarly hereinafter) to Shijiazhuang $\left(14.8{ }^{\circ} \mathrm{C}\right)$, both the wind speed and sunshine hours decreased (from $2.3 \mathrm{~m} / \mathrm{s}$ to $1.5 \mathrm{~m} / \mathrm{s}$, and from $2445 \mathrm{~h}$ to $2140 \mathrm{~h}$, respectively), and the variation of open water evaporation caused by air temperature may be overwhelmed by that caused by wind speed and sunshine hours. 
Open water evaporation was similar between the middle three weather stations (Xingtai, Anyang, and Xinxiang), because of the interaction of air temperature, wind speed, and sunshine hours. In more detail, Xingtai had moderate air temperatures $\left(15.1{ }^{\circ} \mathrm{C}\right)$, low wind speeds $(1.7 \mathrm{~m} / \mathrm{s})$, and large sunshine hours $(2011 \mathrm{~h})$, while Anyang had low air temperature $\left(14.5{ }^{\circ} \mathrm{C}\right)$, large wind speed $(2.3 \mathrm{~m} / \mathrm{s})$, and small sunshine hours $(1825 \mathrm{~h})$, and Xinxiang had high air temperature $\left(15.5{ }^{\circ} \mathrm{C}\right)$, moderate wind speed $(2.1 \mathrm{~m} / \mathrm{s})$, and moderate sunshine hours (1957 h). Open water evaporation of the southern four weather stations (Zhengzhou, Baofeng, Nanyang, and Laohekou) decreased sequentially southward, due mainly to the decrease of sunshine hours. For instance, annual mean sunshine hours in Laohekou from 2000 to 2014 was 1549 hours, 251 hours shorter than that in Zhengzhou, and annual open water evaporation of the former one was $1004 \mathrm{~mm}$, $30 \%$ higher than the latter one.

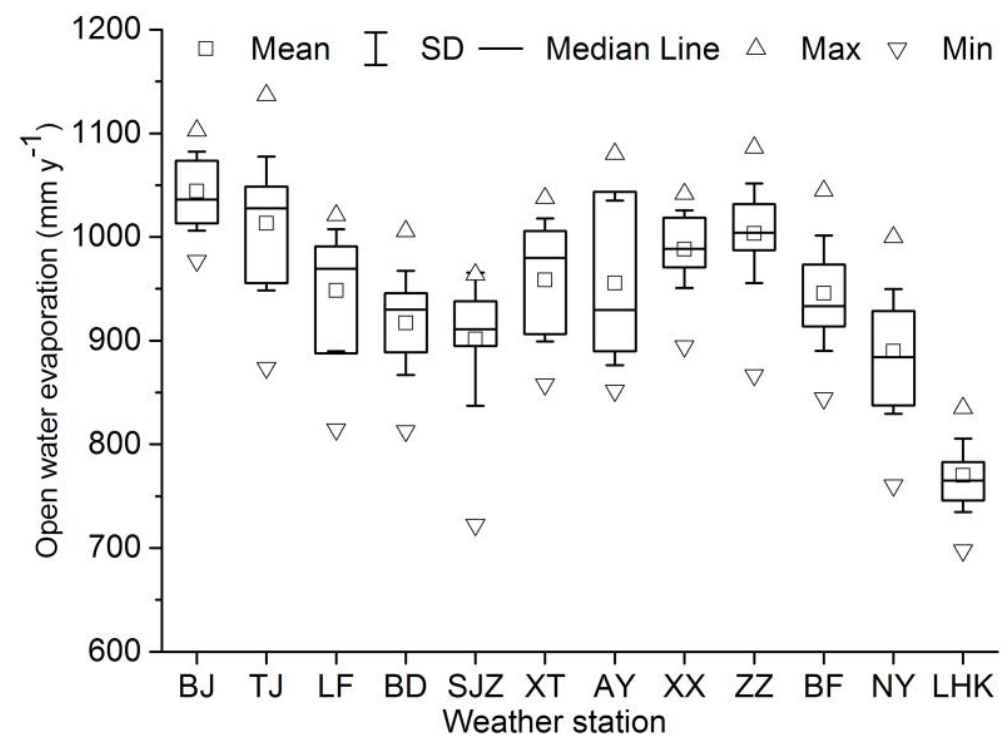

Fig. 3 Annual calculated open water evaporation using the Penman equation at different weather stations along MR-SNWTP from 2000 to 2014 
Monthly open water evaporation rates, not only the mean value, but also the maximum and minimum value, increased month by month, with the peak value in May (Fig. 4). For all 12 weather stations, the mean air temperature in July was the highest, and the largest wind speeds were generally recorded in March or April, but May had the largest sunshine hours, with an average value of 224 hours, $37 \%$ more than that in July, resulting in the intense evaporation. The standard deviation from March to August was higher than that from September to February, suggesting a more significant variability of open water evaporation in spring and summer than that in autumn and winter. Along the whole canal of MR-SNWTP, monthly open water evaporation rate in the north varied more obviously than that in the south. For example, the ratio between the maximum and minimum value of monthly open water evaporation rate in Langfang was 3.67, while it was only 2.36 in Laohekou. 


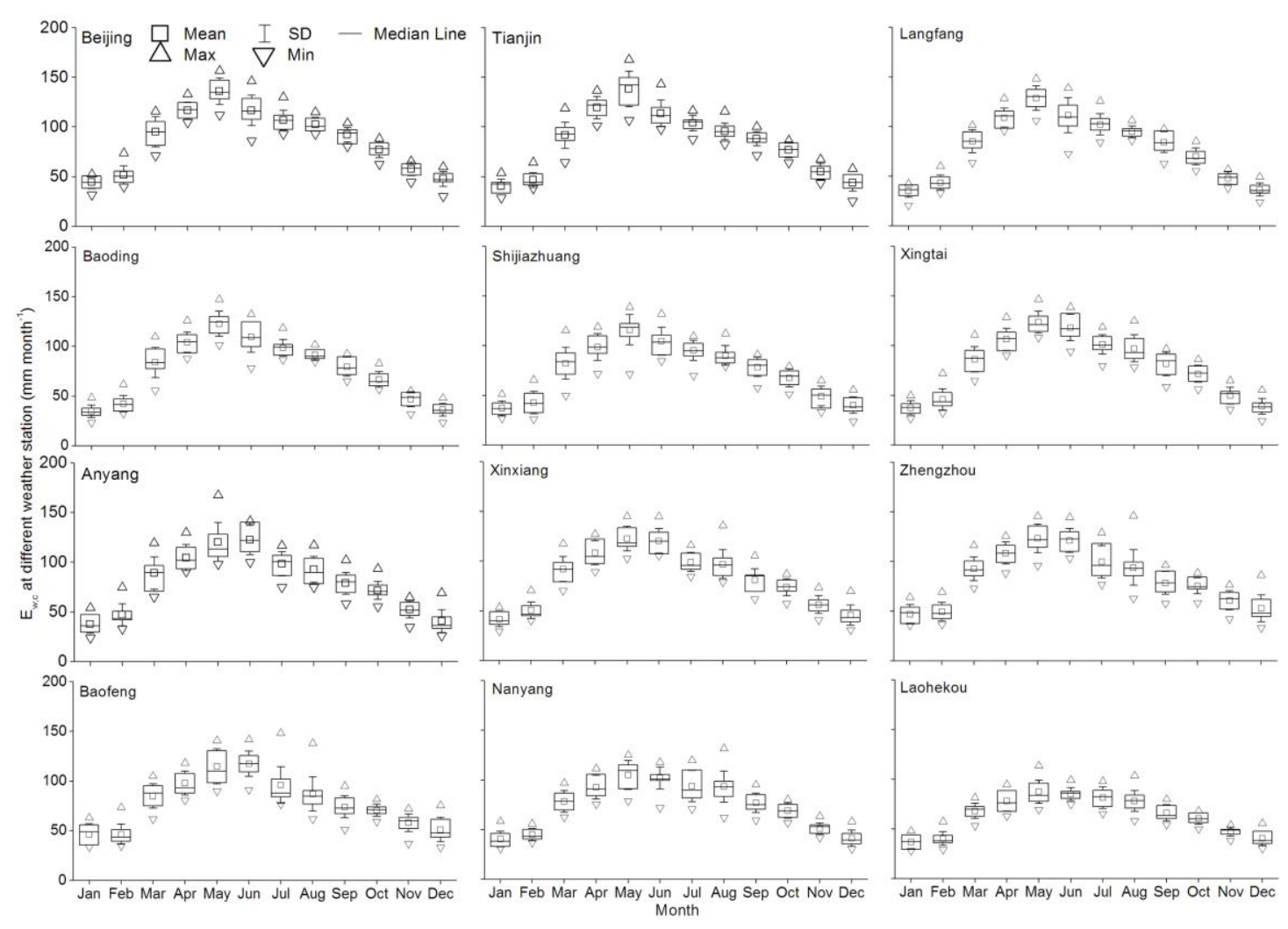

Fig. 4 Monthly calculated open water evaporation using the Penman equation at different weather stations along MR-SNWTP from 2000 to 2014

\subsection{Water loss by evaporation}

Under the planned scenario, the water level of Danjiangkou Reservoir will begin to reduce in May, reaching the lowest levels in July to alleviate summer floods, and maintain high levels in winter and spring to supply sufficient water for diversion. Influenced simultaneously by the water level of Danjiangkou Reservoir and the dispatch scheme of MR-SNWTP, the planned discharge at Taocha, head of MR-SNWTP, is higher in summer and autumn, and lower in winter and spring. Under the 2015 scenario, the actual water level of Danjiangkou Reservoir varied from $152.28 \mathrm{~m}$ to $159.23 \mathrm{~m}$, 
lower evidently than the planned maximal impounded level $(170 \mathrm{~m})$, and the corresponding total water surface area ranged from $693 \mathrm{~km}^{2}$ to $859 \mathrm{~km}^{2}$, with a generally decreasing trend from January to December (Fig. 5). In 2015, the actual mean discharge at Taocha is approximately equal to $60 \mathrm{~m}^{3} \mathrm{~s}^{-1}$ in the prior three months. From April to June, more than $6.60 \times 10^{8} \mathrm{~m}^{3}$ water was transferred, and the mean discharge at Taocha was about $83 \mathrm{~m}^{3} \mathrm{~s}^{-1}$. From July to October, $1.03 \times 10^{9} \mathrm{~m}^{3}$ water was transferred with an average discharge at Taocha of $97 \mathrm{~m}^{3} \mathrm{~s}^{-1}$. From November to December, approximately $4.91 \times 10^{8} \mathrm{~m}^{3}$ water was transferred and mean discharge at Taocha was about $93 \mathrm{~m}^{3} \mathrm{~s}^{-1}$.

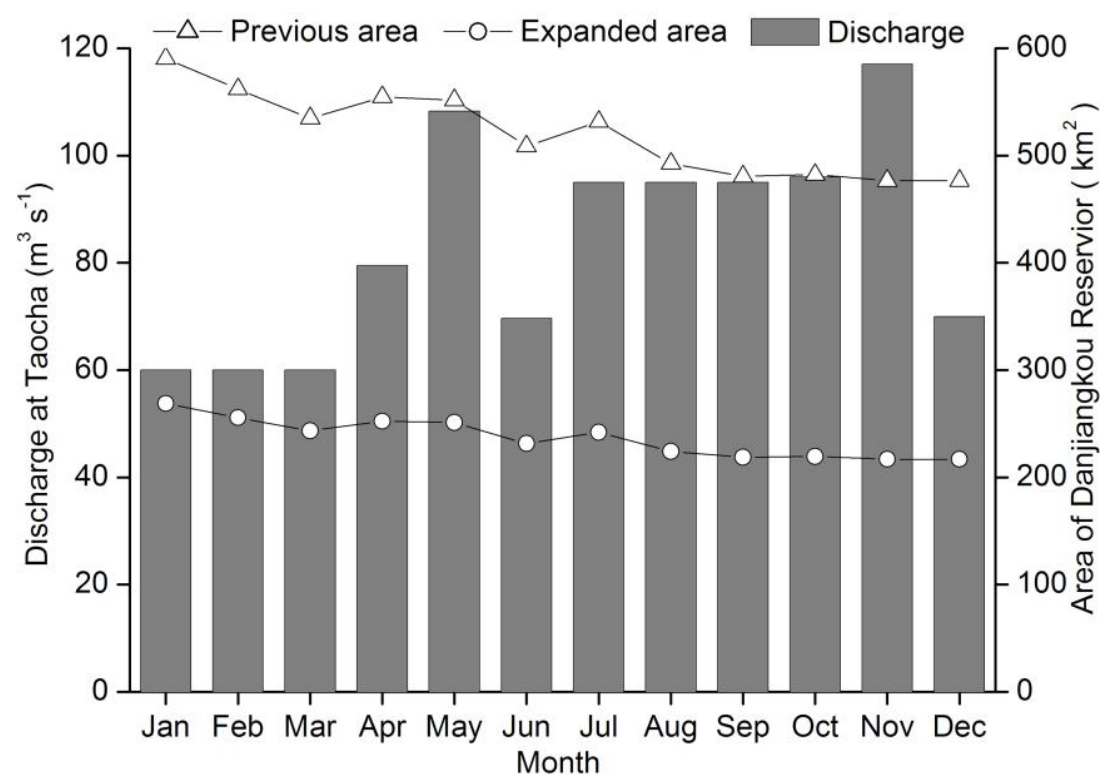

Fig. 5 Monthly mean discharge at Taocha and monthly mean area of Danjiangkou Reservoir under the 2015 scenario

The evaporative width of the canal varies significantly along MR-SNWTP, interactively affected by the discharge, landform, soil, and other factors. Because water 
is transferred through underground pipes in Beijing, both the evaporative width and the water loss by evaporation in Beijing were neglected. For the other 11 sampled sites, evaporative width generally decreases from Taocha (about $45 \mathrm{~m}$ ) to Tianjin (about 23 m), except Nanyang and Xinxiang with a sharp decrease (Fig. 6). The planned discharge at Xinxiang account for about $84 \%$ of that at Zhengzhou, but its bottom width of the canal is only $15 \mathrm{~m}, 5 \mathrm{~m}$ narrower than that of Zhengzhou, due to construction limitations caused by the roads along the canal. Therefore, the monthly mean evaporative width decreases from $30.0-34.5 \mathrm{~m}$ at Zhengzhou to $24.0-28.0 \mathrm{~m}$ at Xinxiang. The reason for the decrease of evaporative width at Nanyang is similar.

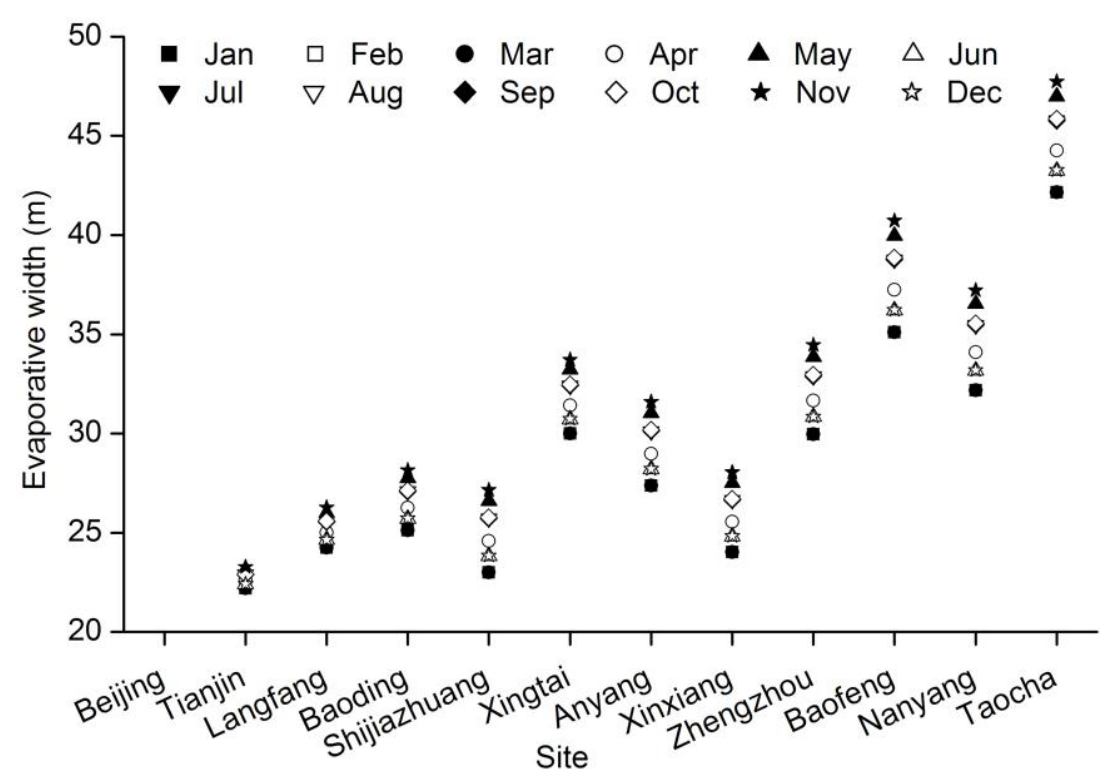

Fig. 6 Monthly calculated evaporative width at different sites along MR-SNWTP under the 2015 scenario

Under the planned scenario and mean climatic conditions from 2000 to 2014, the total water loss by evaporation from MR-SNWTP was $9.00 \times 10^{8} \mathrm{~m}^{3}$ (Fig. 7a), and the 
increased water loss directly due to MR-SNWTP construction (from the canal and expanded reservoir) was approximately $3.17 \times 10^{8} \mathrm{~m}^{3}, 3.34 \%$ of the planned total aqueduct diversion $\left(9.5 \times 10^{9} \mathrm{~m}^{3}\right)$. Under the 2015 scenario, the actual total water loss by evaporation was $6.43 \times 10^{8} \mathrm{~m}^{3}, 24.26 \%$ of the aqueduct diversion in $2015\left(2.65 \times 10^{9} \mathrm{~m}^{3}\right)$, significantly higher than the proportion under the planned scenario. Among the total evaporation loss in 2015, the canal, previous reservoir, and expanded reservoir accounted for $5.98 \%, 64.61 \%$, and $29.41 \%$, respectively (Fig. 7 b), indicating the increased water loss directly resulting from MR-SNWTP construction was approximately $2.27 \times 10^{8} \mathrm{~m}^{3}$. Therefore, when water loss from the previously existing reservoir is subtracted, new construction caused the loss of $8.57 \%$ of the actual aqueduct diversion in 2015. Water loss by evaporation from MR-SNWTP followed a seasonal cycle with the peaking value in May, as a result of higher evaporation rate (Fig. 4) and larger evaporative area (Fig. 5).
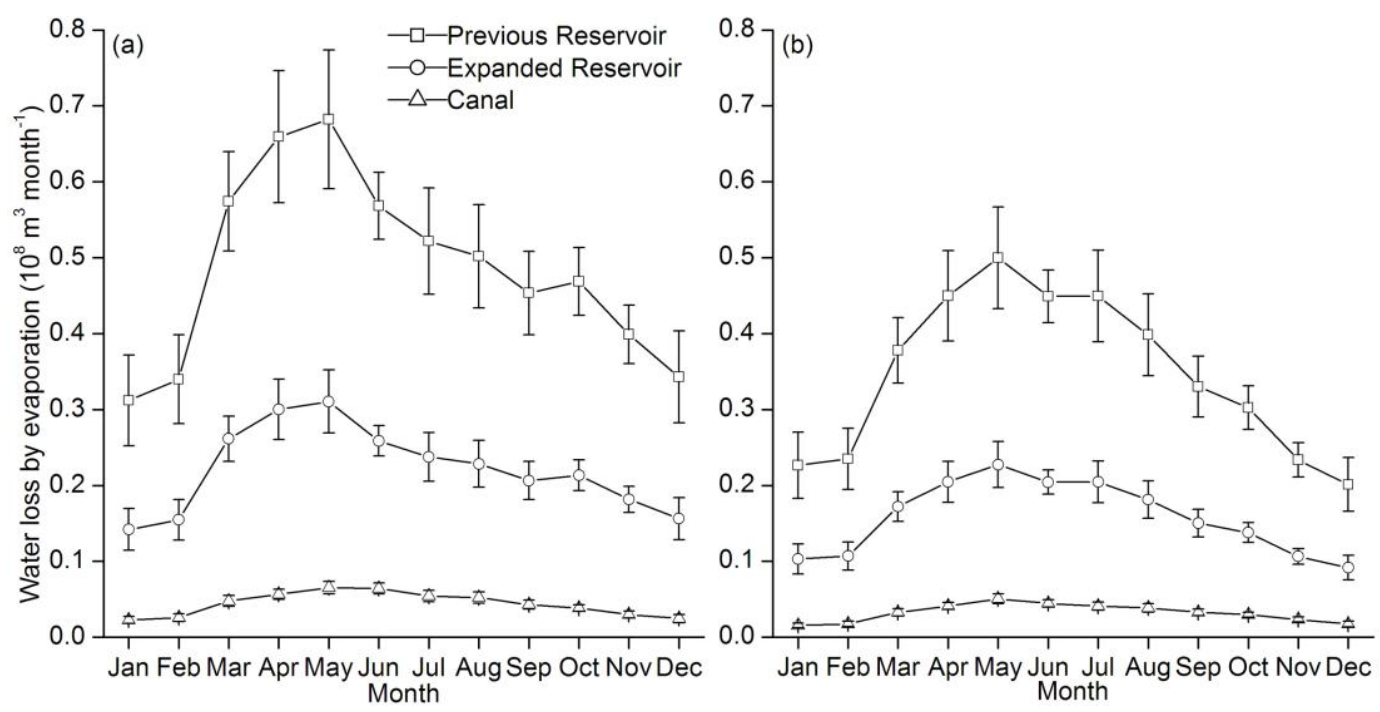

Fig. 7 Monthly water loss by evaporation from the canal and reservoir of MR-SNWTP. (a) Under the planned scenario. (b) Under the 2015 scenario 
Under the planned scenario and mean precipitation of all nearby national weather stations of MR-SNWTP from 2000 to 2014 , approximately $8.64 \times 10^{8} \mathrm{~m}^{3}$ water will fall directly into the reservoir and canal of MR-SNWTP every year (Fig. 8). Evaporation is higher than precipitation in spring and winter, and lower than precipitation in summer, especially in July and August. In autumn, there is no evident difference between them. At an annual scale, the variability of precipitation is much stronger than that of evaporation, especially in July and August.

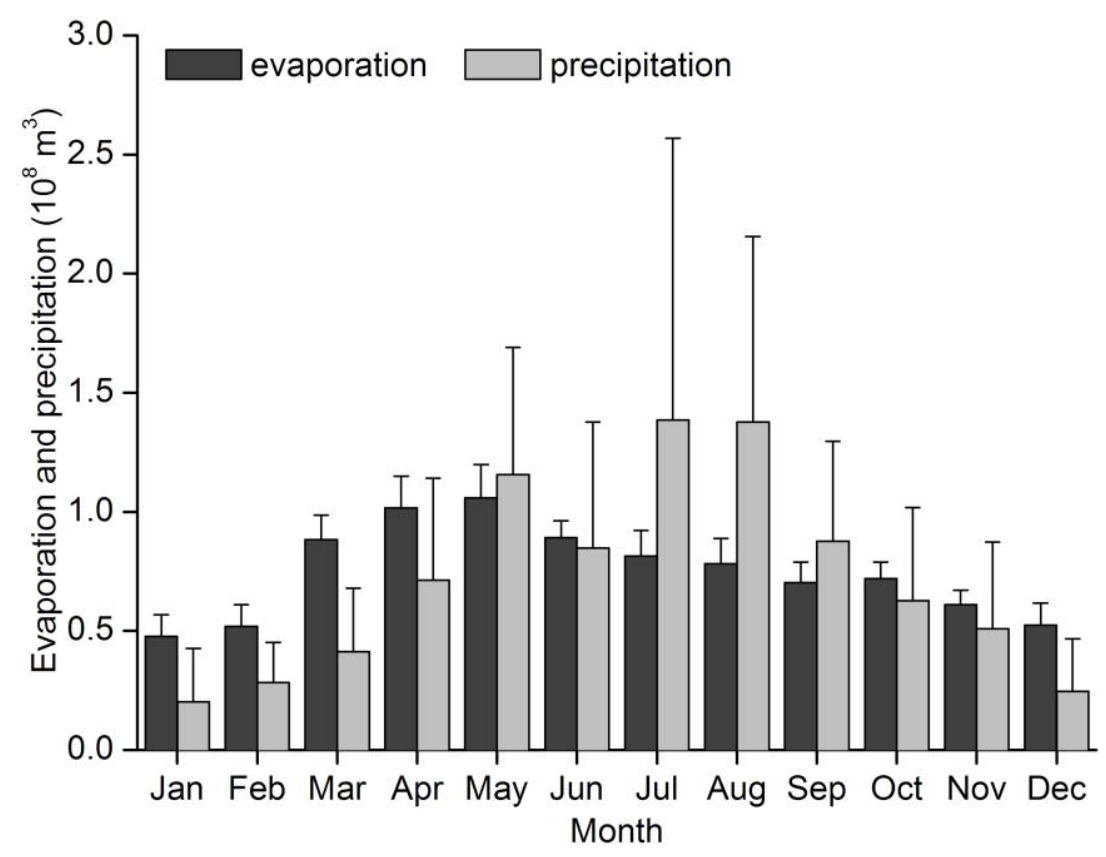

Fig. 8 Comparison of monthly evaporation loss and precipitation of MR-SNWTP under the planned scenario

\section{Discussion}

This study showed that open water evaporation rate decreased generally from north 
to south along MR-SNWTP, and was affected synchronously by energy, aerodynamic, and heat conditions, similar to the findings of ER-SNWTP in Jiangsu Province (Qiu et al. 2011). Correlation analysis revealed that open water evaporation rate has a significant positive relation with air temperature, wind speed and sunshine hours, and a significant negative relation with vapor pressure. However, there was no evident difference of vapor pressure along the MR-SNWTP, indicating that the variation of open water evaporation between different weather stations is mainly due to the difference of air temperature, wind speed and sunshine hours. The results of sensitivity analysis (Zhan et al. 1996) showed that, under the mean climatic conditions from 2000-2014, with $1{ }^{\circ} \mathrm{C}, 0.1 \mathrm{~m} / \mathrm{s}$ and $100 \mathrm{~h}$ increase of annual mean air temperature, wind speed, and sunshine hours, the open water evaporation will increase $0.64 \% \pm 0.28 \%$ (average \pm standard deviation, similarly hereinafter), $1.21 \% \pm 0.19 \%$, and $1.48 \% \pm 0.15 \%$, respectively. Taking Beijing and Shijiazhuang for example, annual mean air temperature, wind speed, and sunshine hours of the former one from 2000 to 2014 were $1.3{ }^{\circ} \mathrm{C}$ lower, $0.8 \mathrm{~m} / \mathrm{s}$ higher and $305 \mathrm{~h}$ larger than the latter one, respectively, and the difference of open water evaporation between these two sites caused by air temperature $(-0.83 \% \pm 0.36 \%$ of annual open water evaporation in Beijing, “+” indicates increase and “-” indicates decrease, similarly hereinafter) would be overwhelmed by that caused by wind speed $(+9.68 \% \pm 1.52 \%)$ and sunshine hours $(+4.51 \% \pm 0.46 \%)$, and this is consistent with the actual difference of open water evaporation between them $(+13.67 \%)$. 
The findings of this study demonstrate that water loss by evaporation from MR-SNWTP accounts for $9.47 \%$ of the total aqueduct diversion under the planned scenario, which is higher than that of the Central Arizona Project in United States (3.60\%, CAP 2013), but lower than that of ER-SNWTP in Jiangsu Province (17.46\%, Qiu et al. 2011). Of this total evaporative loss, approximately $65 \%$ was from the previous reservoir, and less than $6 \%$ was from the canal, which was consistent with the finding of ER-SNWTP in Jiangsu Province (Qiu et al. 2011). From the perspective of water loss, the efficiency of MR-SNWTP will improve in the future with more water diversion. Taking the canal for example, we know that the variation of flow rate ( $\Delta Q$, $\left.\mathrm{m}^{3} \mathrm{~s}^{-1}\right)$ is more significant than the variation of evaporative width $\left(\Delta W_{e}, \mathrm{~m}\right)$ for a trapeziform canal $\left(\Delta Q=-\operatorname{Vtg} \beta\left(\Delta W_{e}^{2}+2 W_{e} \Delta W_{e}\right) / 4\right)$, indicating that with a $\mathrm{x} \%$ increase of water diversion, the increase percentage of evaporative width and accompanying evaporative loss from the open canal will be lower evidently than $\mathrm{x} \%$, thus the proportion of water loss by canal evaporation accounting for total water diversion will decrease. For MR-SNWTP, water diversion increased 3.6 times from $2.65 \times 10^{9} \mathrm{~m}^{3}$ (2015 scenario) to $9.5 \times 10^{9} \mathrm{~m}^{3}$ (planned scenario), however, water loss from the canal only increased 1.4 times from $0.38 \times 10^{8} \mathrm{~m}^{3}$ to $0.52 \times 10^{8} \mathrm{~m}^{3}$, and the corresponding percentage accounting for total water diversion decreased from $1.43 \%$ to $0.55 \%$. For the reservoir, the percentage of evaporation accounting for the water resources available from small reservoirs was more than that from large ones (Maestre-Valero et al. 2013), indicating that with the rise of water level in Danjiangkou 
Reservoir, the percentage of water lost to evaporation by reservoir will decrease. Therefore, the more water is transferred, the lower proportion of water diversion will evaporate.

Though water loss by evaporation from the MR-SNWTP can be estimated by field experiments and the Penman equation, there are still some uncertainties. First, the formula $\left(E_{m, c a}=1.0372 E_{m, w s}\right)$ for transferring open water evaporation at nearby weather stations to that in the canal was based on limited field data measured in July. Though water loss from the canal accounted for less than $6 \%$ of total water loss from the MR-SNWTP, the utilization of this formula for other months may lead to some misestimates. Therefore, more field measurements in different seasons are necessary to validate and perfect this formula. Second, the canal width may be different from one site to another along the MR-SNWTP, and the average width controlled by a given weather station was assumed to be equal to the canal width near it, which could have lead to misestimates of water loss from the canal. According to the field measurements, the canal width near all the national weather stations varied from $50.0 \mathrm{~m}$ to $68.3 \mathrm{~m}$, with an average value of $56.1 \mathrm{~m}$, and the relative deviation can achieve approximatively $16.3 \%$ of water loss from the canal due to the change of canal width between the maximum and minimum value, i.e. less than $1 \%$ of total water loss from the MR-SNWTP, indicating that the assumption about the canal width was acceptable. Third, this study only analyzed the efficiency of the MR-SNWTP from the perspective of water loss, but its integrated efficiency about economy, ecology and environment remains unclear (Barnett 
et al. 2015). Some previous studies show that while the SNWTP is diverting water from south to north, inefficient agricultural production consumes about $75 \%$ of the water resources in the NCP (Barnett et al. 2015), and over 69\% of the reaches in the NCP are unable to support fisheries and wildlife owing to water pollution (He et al. 2007). Therefore, how to improve the water use efficiency of the MR-SNWTP needs further research. Fourth, this study only considered the vertical supplement of precipitation falling into the open reservoir and canal, however surface runoff and groundwater flow were also important water supplements to the MR-SNWTP, which have to be studied deeply in the future based on field experiments and hydrological models. Moreover, though the total amount of precipitation was generally in balance with water loss by evaporation from 2000 to 2014, its variability was higher than that of evaporation, indicating that water loss by evaporation in some months or years may be higher than the contemporaneous precipitation, and this should be considered for the sustainable management of the MR-SNWTP.

\section{Conclusions}

This study provides a first exploration of water loss by evaporation from the MR-SNWTP based on field measurements and mathematical models. The results of this work fill a knowledge gap in our understanding of water loss from the world's largest water transfer project, and could be of critical importance for the sustainable management of the MR-SNWTP and water resources in the NCP. The key findings of this study are summarized as: 
(1) Annual open water evaporation along the MR-SNWTP decreased from north to south, and was affected synchronously by energy, aerodynamic, and heat conditions. Monthly open water evaporation was the highest in May, and was more variable in the north than that in the south.

(2) Under the planned scenario, the total water loss by evaporation was approximately $9.00 \times 10^{8} \mathrm{~m}^{3}$, of which $35.28 \%$ directly resulted from the construction of the MR-SNWTP. Under the 2015 scenario, about $6.43 \times 10^{8} \mathrm{~m}^{3}$ water was lost to evaporation, and the canal and expanded reservoir accounted for $5.98 \%$ and $29.41 \%$ of this value, respectively.

(3) The proportion of increased water loss by evaporation accounted for $8.57 \%$ the aqueduct diversion under the 2015 scenario, and was significantly higher than that under the planned scenario (3.34\%). The efficiency of the MR-SNWTP from the perspective of water loss will improve in the future with more water being transferred.

\section{Appendix}

The slope of the relationship between saturation vapor pressure and temperature, $\Delta$, at a given temperature is given by (Allen et al. 1998).

$$
\begin{gathered}
\Delta=\frac{4098\left[0.6108 \exp \left(\frac{17.27 T_{a}}{T_{a}+237.3}\right)\right]}{\left(T_{a}+237.3\right)^{2}} \\
T_{a}=\frac{T_{\max }+T_{\min }}{2}
\end{gathered}
$$

where $T_{a}$ is daily mean air temperature $\left({ }^{\circ} \mathrm{C}\right) ; T_{\max }$ is daily maximum air temperature $\left({ }^{\circ} \mathrm{C}\right) ; T_{\min }$ is daily minimum air temperature $\left({ }^{\circ} \mathrm{C}\right)$. 
The psychrometric constant, $\gamma$, is given by:

$$
\gamma=\frac{C_{p} P}{\varepsilon \lambda}=0.665 \times 10^{-3} P
$$

where $C_{p}$ is specific heat at constant pressure $\left(1013 \mathrm{~J} \mathrm{~kg}^{-1}{ }^{\circ} \mathrm{C}^{-1}\right) ; \quad P$ is atmospheric pressure $(\mathrm{kPa}) ; \varepsilon$ is ratio molecular weight of water vapor to dry air $(0.622) ; \lambda$ is latent heat of vaporization $\left(2.45 \mathrm{MJ} \mathrm{kg}^{-1}\right)$.

The net radiation at the surface, $R_{n}$, is the difference between the incoming net short wave radiation and the outgoing net long wave radiation (Allen et al. 1998; Valiantzas 2006).

$$
\begin{gathered}
R_{n}=R_{n s}-R_{n l} \\
R_{n s}=(1-\alpha) R_{s} \\
R_{s}=\left(a_{s}+b_{s} \frac{n}{N}\right) R_{a} \\
R_{a}=\frac{24 \times 60}{\pi} G_{s c} d_{r}\left[\omega_{s} \sin (\phi) \sin (\delta)+\sin \left(\omega_{s}\right) \cos (\phi) \cos (\delta)\right] \\
R_{n l}=\sigma\left(T_{a}+273.15\right)^{4}\left(0.34-0.14 \sqrt{e_{a}}\right)\left(1.35 \frac{R_{s}}{R_{s o}}-0.35\right) \\
R_{s o}=\left(0.75+2 \times 10^{-5} Z\right) R_{a} \\
d_{r}=1+0.033 \cos \left(\frac{2 \pi}{365} J\right) \\
\delta=0.409 \sin \left(\frac{2 \pi}{365} J-1.39\right) \\
\omega_{s}=\arccos (-\tan (\phi) \tan (\delta)) \\
N=\frac{24}{\pi} \omega_{s}
\end{gathered}
$$

where $R_{n s}$ is the incoming net short wave radiation $\left(\mathrm{MJ} \mathrm{m} \mathrm{m}^{-2} \mathrm{~d}^{-1}\right) ; R_{n l}$ is the outgoing net long wave radiation $\left(\mathrm{MJ} \mathrm{m}^{-2} \mathrm{~d}^{-1}\right) ; \alpha$ is reflection coefficient or albedo, and a typical value of $\alpha$ for open water surfaces is 0.08 (Allen et al. 1998); $R_{s}$ is solar 
radiation $\left(\mathrm{MJ} \mathrm{m}^{-2} \mathrm{~d}^{-1}\right) ; n$ is actual duration of sunshine hours per day (h); $N$ is the maximum possible duration of daylight (h); $a_{s}$ is regression constant, expressing the fraction of extraterrestrial radiation reaching the earth on overcast days $(n=0), a_{s}+b_{s}$ is fraction of extraterrestrial radiation reaching the earth on clear days $(n=N), a_{s}$ and $b_{s}$ are calculated based on the actual solar radiation data in Beijing, Zhengzhou and Nanyang weather stations; $R_{a}$ is extraterrestrial radiation $\left(\mathrm{MJ} \mathrm{m}^{-2} \mathrm{~d}^{-1}\right) ; G_{s c}$ is solar constant $\left(0.082 \mathrm{MJ} \mathrm{m}^{-2} \mathrm{~min}^{-1}\right) ; d_{r}$ is relative distance between the earth and the sun; $\omega_{s}$ is the sunset hour angle (radians); $\phi$ is the latitude of the site (radians); $\delta$ is solar declination (radians); $\sigma$ is Stefan-Boltzmann constant $\left(4.903 \times 10^{-9} \mathrm{MJ} \mathrm{K}^{-4} \mathrm{~m}^{-2}\right.$ $\left.\mathrm{d}^{-1}\right) ; \quad R_{s o}$ is clear sky radiation $\left(\mathrm{MJ} \mathrm{m}^{-2} \mathrm{~d}^{-1}\right) ; Z$ is station altitude above sea level $(\mathrm{m})$; $J$ is the number of Julian day.

Wind function, $f_{(u)}$, is given by:

$$
f_{(u)}=a+b U_{2}
$$

where $a$ and $b$ are wind function coefficients; $U_{2}$ is wind speed at $2 \mathrm{~m}$ height ( $\mathrm{m}$ $\mathrm{s}^{-1}$ ). For the original Penman (1948) equation, $a=1, b=0.536$. Later, Penman (1956) suggested a reduction of the original function by proposing $a=0.5$ and $b=0.536$. Linacre (1993) reduced further the value of the wind function proposing $a=0$ and $b=0.536$, which were used for the calculation of evaporation in this paper.

Saturation vapor pressure, $e_{s}$, and actual vapor pressure, $e_{a}$, are given by (Allen et al. 1998):

$$
e_{s}=\frac{0.6108 \exp \left(\frac{17.27 T_{\max }}{T_{\max }+237.3}\right)+0.6108 \exp \left(\frac{17.27 T_{\min }}{T_{\min }+237.3}\right)}{2}
$$




$$
e_{a}=\frac{R H}{100} e_{s}
$$

where $R H$ is daily mean relative humidity (\%).

$$
\begin{gathered}
\rho_{a}=1.293 \times \frac{P}{101.325} \times \frac{273.15}{T_{a}+273.15} \\
r_{a}=\frac{\ln \left(\frac{Z_{m}-d}{Z_{o m}}\right) \ln \left(\frac{Z_{h}-d}{Z_{o h}}\right)}{k^{2} U_{2}}
\end{gathered}
$$

where $Z_{m}$ is the height of wind measurements (m); $d$ is zero-plane displacement height (m), and it is common to use $d=0$ for water surfaces (Tanny et al. 2008); $Z_{\text {om }}$ is the roughness length for momentum transfer (m), equal to $2 \times$ $10^{-4} \mathrm{~m}$ for open water (Mohamed et al. 2012); $Z_{h}$ is the height of humidity measurements $(\mathrm{m}) ; Z_{\text {oh }}$ is the roughness length for vapor and heat transfer $(\mathrm{m})$, equal to $2 \times 10^{-5} \mathrm{~m}$ for open water (Mohamed et al. 2012); $k$ the van Karman constant (0.41).

\section{Acknowledgements}

We would like to thank two anonymous reviewers for their valuable and constructive comments, and Yuyang Bao and Nanhuanuowa Zhu for their assistance in performing experiments. This work was supported by National Geographic Air and Water Conservation Fund (GEFC08-12) and the National Science Foundation of China (NSFC 41301013 and 91425301).

Conflict of Interest. The authors declare that they have no conflict of interest. 


\section{References}

Allen RG, Pereira LS, Raes D, Smith M (1998) Crop evapotranspiration - guidelines for computing crop water requirements. FAO Irrigation and Drainage Paper 56, Rome

Barnett J, Rogers S, Webber M, Finlayson B, Wang M (2015) Transfer project cannot meet China's water needs. Nature 527: 295-297

Central Arizona Project (CAP) (2013). System water losses for 2012

Construction and Administration Bureau of South to North Water Transfer Project, Ministry of Water Resources of China (CAB-SNWTP) (2003) Introduction of South to North Water Transfer Project's plan. China Water Resources (1): 56-62 (In Chinese)

Food and Agriculture Organization of the United Nations (FAO) (2014) Water and poverty, an issue of life and livelihoods. http://www.fao.org/nr/water/issues/topics_scarcity_poverty.html

Gu WQ, Shao DG, Jiang YF (2012) Risk evaluation of water shortage in source area of Middle Route Project for South-North water transfer in China. Water Resources Management 26: 3479-3493

Guan G, Clemmens AJ, Kacerek TF, Wahlin BT (2011) Applying water-level difference control to Central Arizona Project. Journal of Irrigation and Drainage Engineering 137: $747-753$

He CS, Cheng SK, Luo Y (2007) Water diversions and china's water shortage crisis. In: Robinson PJ, Jones T, Woo MK (eds) Managing water resources in a changing 
physical and social environment. IGU Home of Geography Publication Series, Rome, pp 89-102

He CS, He XY, Fu L (2010) China's South-to-North Water Transfer Project: is it needed? Geography Compass 4: 1312-1323

Hubei Daily (HD) (2015) One year after the officially running of the Middle Route of $\begin{array}{llll}\text { South-North } & \text { Water } & \text { Transfer }\end{array}$ http://hbrb.cnhubei.com/HTML/hbrb/20151212/hbrb2800583.html (In Chinese)

Jeremy B (2003) China: the South-North Water Transfer Project-is it justified? Water Policy 5: 1-28

Li BS, Zhou PJ, Wang XY, Zhu LD (2013) Opportunities and eco-environmental of cascade hydropower development and water diversion projects in Hanjiang river basin. Journal of the Geological Society of India 82: 692-700

Li LC, Zhang LP, Xia J, Gippe CJ, Wang RC, Zeng SD (2015) Implications of modelled climate and land cover changes on runoff in the Middle Route of the South to North Water Transfer Project in China. Water Resources Management 29: 2563-2579

Linacre ET (1993) Data-sparse estimation of lake evaporation, using a simplified Penman equation. Agricultural and Forest Meteorology 64: 237-256

Ma WJ, Mao ZQ, Yu ZR, Mensvoort MEFV, Driessen PM (2008) Effects of saline water irrigation on soil salinity and yield of winter wheat-maize in North China Plain. Irrigation and Drainage Systems 22: 3-18 
Maestre-Valero JF, Martínez-Granados D, Martínez-Alvarez V, Calatrava J (2013) Socio-economic impact of evaporation losses from reservoirs under past, current and future water availability scenarios in the semi-arid segura basin. Water Resources Management 27: 1411-1426

Manning R (1891) On the flow of water in open channels and pipes. Transactions of the Institution of Civil Engineers of Ireland 20: 161-207

Matete M, Hassan R (2006) Integrated ecological economics accounting approach to evaluation of inter-basin water transfers: an application to the Lesotho Highlands Water Project. Ecological Economics 60: 246-259

Mayhew S (2015) A dictionary of geography (5 ed.). Oxford University Press, London Mohamed YA, Bastiaanssen WGM, Savenije HHG, van den Hurk BJJM, Finlayson CM (2012) Wetland versus open water evaporation: an analysis and literature review. Physics and Chemistry of the Earth 47-48: 114-121

Monteith JL (1965) Evaporation and environment. In: Proceedings of the 19th Symposium of the Society for Experimental Biology. Cambridge University Press, New York, pp 205-233

Nash JE, Sutcliffe JV (1970) River flow forecasting through conceptual models Part Ia discussion of principles. Journal of Hydrology 10: 282-290

National Bureau of Statistics of China (NBSC) (2015). China Statistical Yearbook 2015. China Statistics Press, Beijing (In Chinese)

Oki T, Kanae S (2006) Global hydrological cycles and world water resources. Science 
313: $1068-1072$

Penman HL (1948) Natural evaporation from open water, bare soil and grass. Proceedings of the Royal Society of London: Series A 193: 120-145

Penman HL (1956) Evaporation: an introductory survey. Netherland Journal Agricultural Science 4: 9-29

Priestley CHB, Taylor RJ (1972) On the assessment of surface heat flux and evaporation using large-scale parameters. Monthly Weather Review 100: 81-92

Qiu BY, Wang F, Feng XL, Huang HT, Yang XL (2011) Effects of water surface evaporation on water transfer efficiency for Jiangsu section of South-to-North Water Diversion Project. Journal of Drainage and Irrigation Machinery Engineering 29: 219-223 (In Chinese with English abstract)

Quinn P, Beven K, Chevallier P, Planchon O (1991) The prediction of hillslope flow paths for distributed hydrological modelling using digital terrain models. Hydrological Processes 5: 59-79

Rey D, Garrido A, Calatrava J (2016) An innovative option contract for allocating water in inter-basin transfers: the case of the Tagus-Segura Transfer in Spain. Water Resources Management 30: 1165-1182

Roderick ML, Farquhar GD (2002) The cause of decreased pan evaporation over the past 50 years. Science 298: 1410-1411

Tanny J, Cohen S, Assouline S, Lange F, Grava A, Berger D, Teltch B, Parlange MB (2008) Evaporation from a small water reservoir: direct measurements and 
estimates. Journal of Hydrology 351: 218-229

Valiantzas JD (2006) Simplified versions for the Penman evaporation equation using routine weather data. Journal of Hydrology 331: 690-702

Vörösmarty CJ, Green P, Salisbury J, Lammers RB (2000) Global water resources: vulnerability from climate change and population growth. Science 289: 284-288

Wang CY, Yu LS, Ma B, Jiang RG (2009a) Composite geomembrane's anti-seepage application in SNWD. Water Conservancy Science and Technology and Economy 15: 738-739 (In Chinese with English abstract)

Wang YJ, Xie ZK, Malhi SS, Vera CL, Zhang YB, Wang JN (2009b) Effects of rainfall harvesting and mulching technologies on water use efficiency and crop yield in the semi-arid Loess Plateau, China. Agricultural Water Management 96: 374-382

Wei YQ, Davidson B, Chen DL, White R, Li BG, Zhang JB (2007) Can contingent valuation be used to measure the in situ value of groundwater on the North China Plain? Water Resources Management 21: 1735-1749

World Commission on Dams (WCD) (2000) Dams and development: a new framework for decision-making. Earthscan Publications, London

Wu JG, Huang JH, Han XG, Xie ZQ, Gao XM (2003). Three-Gorges Dam-experiment in habitat fragmentation? Science 300: 1239-1240

Xinhua News (XN) (2014) Is the South-North Water Transfer Project failed? http://news.xinhuanet.com/politics/2014-12/27/c_1113798357.htm (In Chinese)

Yan BW, Chen L (2013) Coincidence probability of precipitation for the middle route of 
South-to-North water transfer project in China. Journal of Hydrology 499: 19-26

Yevjevich V (2001) Water diversions and interbasin transfers. Water International 26: $342-348$

Zhan X, Kustas WP, Humes KS (1996) An intercomparison study on models of sensible heat flux over partial canopy surfaces with remotely sensed surface temperature. Remote Sensing of Environment 58: 242-256

Zhang Q, Qi TY, Li JF, Singhe VP, Wang ZZ (2015) Spatiotemporal variations of pan evaporation in China during 1960-2005: changing patterns and causes. International Journal of Climatology 35: 903-912

Zhang QF, Xu ZF, Shen ZH, Li SY, Wang SS (2009) The Han River watershed management initiative for the South-to-North Water Transfer project (Middle Route) of China. Environmental Monitoring and Assessment 148: 369-377

Zhao JY (2014) Analysis of the loss of water surface evaporation and its variation characteristics in Zhuzhuang Reservoir. South-to-North Water Transfers and Water Science \& Technology 12: 147-150 (In Chinese with English abstract) 